\title{
Influence of Entrepreneurship Courses and Entrepreneurial Training Against Entrepreneurial Interest
}

\author{
Dewi Andriany ${ }^{1}$, and Mutia Arda ${ }^{2}$ \\ \{dewiandriany@umsu.ac.id ${ }^{1}$ \} \\ ${ }^{1,2}$ University of Muhammadiyah Sumatera Utara, Jalan Kapten Mukhtar Basri No. 3 Medan, Indonesia
}

\begin{abstract}
One of Center for Entrepreneurship Development University of Muhammadiyah Sumatera Utara's missions is to develop new entrepreneurs from the campus environment. For this reason, Center for Entrepreneurship Development University of Muhammadiyah Sumatera Utara is responsible for managing Semester Learning Plan, especially for entrepreneurship courses as well as holding various types of entrepreneurial training conducted regularly to foster entrepreneurial interest for University of Muhammadiyah Sumatera Utara students. This study was intended to answer the question by examining the effect of giving entrepreneurship courses and business training on the entrepreneurial interest of students of Muhammadiyah University of North Sumatra. The sampling technique in this study is quota sampling by setting 100 respondents as research samples. The analysis technique used in this study is multiple regression analysis. The results of this study are giving courses and entrepreneurial training equally have a significant positive effect on the entrepreneurial interest of University Of Muhammadiyah Sumatera Utara students. However, the provision of entrepreneurship courses has a more dominant influence than entrepreneurship training in influencing student interest in entrepreneurship.
\end{abstract}

Keywords: Entrepreneurship, Training, Entrepreneurship Interests.

\section{Introduction}

The importance of entrepreneurship is primarily economic because $25 \%$ of economic growth is triggered by the creation of new businesses, related to this statement (Cuervo,2005) that entrepreneurship leads to wealth creation. (Wennekers, Uhlaner and Thurik,2002) argue equally that entrepreneurship is a driver for the creation of new products (ie innovation) and markets. The three main elements driving entrepreneurship are industry, government and education (Matlay and Mitra, 2002).

The Center for Entrepreneurship Development at University Of Muhammadiyah Sumatera Utara, has a vision as a center of entrepreneurship development that excels in supporting the vision and mission of University Of Muhammadiyah Sumatera Utara. To realize this vision, one of its missions was established to develop new entrepreneurs from the campus environment. The role of entrepreneurs (entrepreneurs) in determining the progress of a nation / state has been proven by several developed countries such as the United States 12\% of its population become entrepreneurs, Japan more than $10 \%$ of its population as entrepreneurs, Singapore and Malaysia more than $7.2 \%$, the number of Indonesian entrepreneurs in in 2016 only $1.65 \%$ of the Indonesian population, (Dewi, 2017).

The university has a big role and has the opportunity to instill an attitude of mental entrepreneurship. Judging from the success of developed countries in America and Europe, 
almost all of the universities insert entrepreneurship material in each of their courses, countries in Asia such as Japan, Singapore and Malaysia also apply entrepreneurship materials for at least two semesters. As an implementation of entrepreneurship development in universities in Indonesia, entrepreneurship education is included in the curriculum with a range of weight between 2 to 3 credits.

At University Of Muhammadiyah Sumatera Utara, to instill an interest in the entrepreneurial spirit not only through the provision of courses but also through the Center for Entrepreneurship Development University of Muhammadiyah Sumatera Utara institution with entrepreneurial training activities. Entrepreneurship lecture implementation is not much different from the teaching of other subjects, namely in the form of teaching theory in a class with a limited duration of time, so that its effectiveness in growing and increasing entrepreneurial interest is still questionable, for it is necessary additional entrepreneurial training.

The presence of Center for Entrepreneurship Development University of Muhammadiyah Sumatera Utara is needed to encourage the entrepreneurial interest of University Of Muhammadiyah Sumatera Utara students in each faculty. At present the role of Center for Entrepreneurship Development has been proven to be able to generate entrepreneurship among students in various business fields such as culinary, agriculture, animal husbandry, and other creative economic fields such as handicrafts, jewelery, and others. This study was intended to answer the question by examining the effect of giving entrepreneurship courses and business training on the entrepreneurial interest of students of University Muhammadiyah of Sumatera Utara.

Research on entrepreneurial interest among students has been widely practiced in Indonesia, such as (Putri, 2017), (Yuliatin, 2017), (Rumijati, 2010). (Putri, 2017), (Yuliatin, 2017) both found that entrepreneurship education influences entrepreneurial interest, on the other hand (Rumijati, 2010) found that learning methods did not have a significant impact on entrepreneurial interest. This study focuses specifically on answering problems in the case of University Of Muhammadiyah Sumatera Utara who provide entrepreneurship courses and routinely hold entrepreneurial training.

\section{Literature Review}

\subsection{Entrepreneurship}

According to the Large Indonesian Language Dictionary, the notion of entrepreneurship is the same as that of entrepreneurs, that is, smart or talented people recognize new products, determine new ways of thinking, determine new ways of production, prepare operations to procure new products, market and regulate their operating capital, (Alwi, 2012). Entrepreneurship is the result of a discipline, the systematic process of applying creativity and innovation in meeting the needs and opportunities in the market (Suryana, 2013). In essence, entrepreneurship is a creative and innovative ability that is used as a basis, tips and resources to create opportunities for success in business or life. The indicators used to measure entrepreneurship courses in this study are: 1) students understand the purpose of entrepreneurship, 2) students know how to find business opportunities, 3) students know the steps to realize a business, 4) students can develop entrepreneurial proposals.

Entrepreneurship is coming to individuals who want to set up their own businesses where they can implement their own ideas (Cubico, Bortolani, Favretto and Sartori, 2010). Entrepreneurship cannot be seen only as the creation of a new business but as a series of constructive steps towards creating a new business (Shane, Locke and Collins, 2003) 
According to (Wagner,2007) the process of creating a new business consists of four stages, namely conception, pregnancy, childhood and adolescence.

\subsection{Training}

The definition of training is: the teaching and learning process by using certain techniques and methods conceptually can be said that training is intended to improve the skills and ability to work of a person or group of people, (Siagian, 2008). Usually those who have worked in an organization whose efficiency, effectiveness and productivity are felt necessary to be able to be directed and pragmatically improved. Training is every effort to improve the performance of their responsibilities, or one job that has to do with their work, (Gomes, 2003). From some of the above understanding, it can be said that training is one of the company's efforts to improve the performance of its employees so that they can work well and can provide good quality service to customers. There are several dimensions and indicators in the training as explained by (Mangkunegara, 2011), the training indicators are as follows: 1) Instructors (mastering the material for an instructor), 2) Participants (enthusiasm for training), 3) Material (according to participants 'components), 4) Method (having clear goals), 5) Objectives (can improve participants' skills).

\subsection{Interest in Entrepreneurship}

Interest is all human actions that arise because of internal encouragement and external stimulation, but will not happen if you are not interested. Interest in entrepreneurship is a sense of interest in becoming an entrepreneur who is willing to carry out activities in managing time, skills and finances for business progress. Entrepreneurial interest is not brought from birth but grows and develops in accordance with the factors that influence. In this study entrepreneurial interest is defined as the desire of students to realize or form a business, with indicators: 1 . The desire to work independently, 2 . The desire to get challenges, 3. The desire to obtain income that is volatile and not small but stable, and 4 . The desire to make something new.

\section{Research Methods}

\subsection{Population and Sample}

The population in this study is all students of Univesity Muhammadiyah of Sumatera Utara. The sample is part of the number and characteristics possessed by a population. Sampling technique in this research is quota sampling by setting 100 respondents as research sample.

\subsection{Validity and Reliability Test}

Based on the results of statistical analysis with the SPSS 22 for Windows program, the results of the validity and reliability tests were obtained as follows:

Table 1. Validity and Reliability Test Results.

\begin{tabular}{lllll}
\hline No & $\begin{array}{l}\text { Corrected } \\
\text { Item-Total } \\
\text { Correlation }\end{array}$ & $\begin{array}{l}\text { Status } \\
\text { Validity }\end{array}$ & $\begin{array}{l}\text { Cronbach's } \\
\text { Alpha }\end{array}$ & $\begin{array}{l}\text { Status } \\
\text { Reliability }\end{array}$ \\
\hline 1 &, 973 & Valid &, 988 & Reliable \\
\hline 2 &, 940 & Valid &, 988 & Reliable \\
\hline
\end{tabular}




\begin{tabular}{lllll}
\hline 3 &, 929 & Valid &, 988 & Reliable \\
\hline 4 &, 917 & Valid &, 989 & Reliable \\
\hline 5 &, 929 & Valid &, 988 & Reliable \\
\hline 6 &, 974 & Valid &, 988 & Reliable \\
\hline 7 &, 917 & Valid &, 989 & Reliable \\
\hline 8 &, 974 & Valid &, 988 & Reliable \\
\hline 9 &, 857 & Valid &, 990 & Reliable \\
\hline 10 &, 917 & Valid &, 989 & Reliable \\
\hline 11 &, 869 & Valid &, 989 & Reliable \\
\hline 12 &, 973 & Valid &, 988 & Reliable \\
\hline 13 &, 940 & Valid &, 988 & Reliable \\
\hline
\end{tabular}

Based on the results of data processing, all instrument items are declared valid because of the corrected item-total correlation value $>\mathrm{r}$ table value $(0.361)$. All instrument items are declared feasible to use, this can be evidenced from the Cronbach's alpha value of all instruments that are greater than the constant value of 0.6 .

\subsection{Analysis Mutiple Linear Regression}

This analysis is used to find out how big the influence of bound variable. Multiple regression method is formulated as follows:

$\mathrm{Y}=\mathrm{a}+\mathrm{b}_{1} \mathrm{X}_{1}+\mathrm{b}_{2} \mathrm{X}_{2}+\mathrm{e}$

$\mathrm{Y}$ : entrepreneurial interest, $\mathrm{a}$ : constanta, $\mathrm{b}_{1}, \mathrm{~b}_{2}$ : multiple regression coefficient, $\mathrm{X}_{1}$ : entrepreneurship course, $\mathrm{X}_{2}$ : entrepreneurship training, e: standart error.

\section{Result And Discussion}

The $t$ value of the tables in this study is 1.660 (by looking at $t$ table at the 0.05 significance level).

Table 2. Partial Significance Test (Test-t)

\begin{tabular}{lllll}
\hline \multirow{2}{*}{ Model } & \multicolumn{2}{l}{ Unstandardized Coefficients } & \multirow{2}{*}{ S } & Sig \\
\cline { 2 - 4 } & $\mathrm{B}$ & Std. Error & & \\
\hline (Constant) & 6,983 & 1,933 & 3,613 &, 000 \\
\hline $\mathrm{X}_{1}$ &, 304 &, 098 & 3,101 &, 003 \\
\hline $\mathrm{X}_{2}$ &, 234 &, 031 & 7,479 &, 000 \\
\hline
\end{tabular}

Based on Table 2 can be explained as follows; The value of t-count $>$ t-table of entrepreneurship course (X1) that is 3,101 > 1,66 and significant value for entrepreneurship course $0,003<$ alpha 0,05 , so variable of entrepreneurship course have positive and significant effect to interest in entrepreneurship for University of Muhammadiyah Sumatera Utara students. The value of $t$-count $>t$-table of entrepreneurship training (X2) is 7,479 $>1.66$ and significant value for the entrepreneurship training of $0.000<$ alpha 0.05 , so that the variable of entrepreneurship training has a positive and significant effect to interest in entrepreneurship for University of Muhammadiyah Sumatera Utara students. 
Table 3. Result of Simultaneous Significance Test (Test-F)

\begin{tabular}{llllll}
\hline Model & Sum of Square & df & Mean Square & f & Sig \\
\hline Regression & 31,580 & 2 & 15,790 & 30,233 &, $000 \mathrm{~b}$ \\
\hline Residual & 50,660 & 97 &, 522 & & \\
\hline Total & 82,240 & 99 & & & \\
\hline
\end{tabular}

Based on Table 3 it is found that a significant level of 0.000 is smaller than alpha 0.05 (5\%). Thus simultaneously entrepreneurship course variable and entrepreneurship training to interest in entrepreneurship for University of Muhammadiyah Sumatera Utara students.

Furthermore, to know the magnitude of the effect of independent variables on the dependent variable is to use the test coefficient determination $\mathrm{R}$ in Table 4:

Table 4. Coefficient of Determination $\left(\mathrm{R}^{2}\right)$

\begin{tabular}{lllll}
\hline Model & $\mathrm{R}$ & $\mathrm{R}$ & $\begin{array}{l}\text { Adjusted } \\
\text { Square }\end{array}$ & $\begin{array}{l}\text { Std. Equare } \\
\text { of } \\
\text { Estimate }\end{array}$ \\
\hline 1 &, $620^{\mathrm{a}}$ &, 384 &, 371 &, 723 \\
\hline
\end{tabular}

The value of Adjusted R Square obtained is 0.371 or $37,1 \%$ indicating the ability of entrepreneurship course variable and entrepreneurship training in explaining the variation or effect that happened on interest in entrepreneurship for University of Muhammadiyah Sumatera Utara students $37,1 \%$, while the rest equal to $62,9 \%$ influenced by other variables beyond this study.

The results of this study indicate that the variables of entrepreneurship course have a more dominant influence to interest in entrepreneurship for University of Muhammadiyah Sumatera Utara students than entrepreneurship training.

Education and training is one of the 9 elements that contribute to entrepreneurship in a country, the importance of this relationship is recognized by (Rideout and Gray,2013) which states that there are three main obstacles to entrepreneurship: social and cultural barriers, lack of capital and lack of education. Entrepreneurial activities derived from entrepreneurial intentions and entrepreneurial education play an important role in them because they can direct entrepreneurial intentions.

For further information, Rideout and Gray (2013) stated that entrepreneurship education increases the likelihood that someone is involved in entrepreneurial activities discussed in Theory of Planned Behavior (TPB) by Ajzen and the model of entrepreneurial event by Shapero. The first model discussed is Theory of Planned Behavior which is used to see the effect on entrepreneurial students on the intention of entrepreneurship (Noel, 2002). Theory of Planned Behavior is built on the idea that people make rational choices and intentions, and that choices and intentions lead to certain behaviors (Küttim, Kallaste, Venesaar and Kiis, 2014). The intention of entrepreneurship generally results in more behavior, when that intention is rare and is maintained for a longer period of time (Noel, 2002). The Shapero Entrepreneurial Event Model was created as a model specifically for entrepreneurial research. It is seen as the first model that describes entrepreneurial intentions (Guerrero, Rialp and Urbano, 2008). Judging from the fact that passivity encourages people's behavior until an event, positively or negatively, violates this passivity (Krueger et al, 2000). Especially for entrepreneurial behavior, losing a job can be a negative event that violates passivity; winning the lottery, on the other hand, can be a positive cause of disrupting passivity (Krueger, Reilly, 
Carsrud, 2000). This can be related to the fact that lack of financing is a barrier to entrepreneurship (Rideout and Gray, 2013).

\section{Conclusions}

From the results of statistical tests it can be concluded that the provision of courses and entrepreneurial training equally have a significant positive effect on the entrepreneurial interest of University Of Muhammadiyah Sumatera Utara students. These results indicate that the provision of entrepreneurship and entrepreneurship training courses that have been carried out by University Of Muhammadiyah Sumatera Utara Examiners proved to increase entrepreneurial interest in students, especially the provision of entrepreneurship courses that have a more dominant influence than entrepreneurship training. This is because students are required to participate directly in making group business proposals.

The next researcher is advised to explore other factors that can increase students' interest in entrepreneurship, so that it is expected that the University of Muhammadiyah Sumatera Utara Center for Entrepreneurship Development can take the right policies in order to further increase student interest in entrepreneurship.

\section{References}

[1] Alwi, Hasan., 2012. Kamus Besar Bahasa Indonesia. Balai Pustaka. Jakarta, $4^{\text {th }}$ Edition.

[2] Cubico, S., Bortolani, E., Favretto, G., Sartori, R., 2010. Describing the entrepreneurial profile: the entrepreneurial aptitude test (TAI). International Journal of Entrepreneurship and Small Business. Vol. 11. No. 4. Pp.424-435.

[3] Cuervo, A., 2005. Individual and environmental determinants of entrepreneurship. The International Entrepreneurship and Management Journal. Vol.1. No. 3. Pp.293-311.

[4] Dewi, Sutrisna, S.K., 2017. Konsep dan Pengembangan Kewirausahaan di Indonesia, Deepublish, Yogyakarta, $1^{\text {st }}$ edition.

[5] Gomes, Faustino Cardoso. 2003. Manajemen Sumber Daya Manusia. Andi Offset. Jakarta.

[6] Guerrero, M., Rialp, J., \& Urbano, D., 2008. The impact of desirability and feasibility on entrepreneurial intentions: A structural equation model. International Entrepreneurship and Management Journal. Vol.4. No. 1. Pp.35-50.

[7] Krueger, N. F., Reilly, M. D., Carsrud, A. L., 2000. Competing models of entrepreneurial intentions. Journal of business venturing. Vol. 15. No. 5. Pp.411-432.

[8] Küttim, M., Kallaste, M., Venesaar, U., \& Kiis, A., 2014. Entrepreneurship education at university level and students' entrepreneurial intentions. Procedia-Social and Behavioral Sciences. No.110. Pp.658-668.

[9] Mangkunegara, Anwar Prabu. 2011. Manajemen Sumber Daya Manusia. PT.Remaja Rosda Karya. Bandung.

[10] Matlay, H., \& Mitra, J. (2002). Entrepreneurship and learning: the double act in the triple helix. The International Journal of Entrepreneurship and Innovation. Vol. 3. No. 1. Pp.7-16.

[11] Noel, T. W., 2002. Effects of entrepreneurial education on intent to open a business: An exploratory study. Journal of Entrepreneurship Education. Vol.5. No.3.

[12] Putri, N L.W.W., Sujana, I N., Suwena, K.R., 2017. Pengaruh Pendidikan Kewirausahaan Terhadap Minat Mahasiswa Untuk Berwirausaha Pada Mahasiswa 
Pendidikan Ekonomi Universitas Pendidikan Ganesha. Jurnal Jurusan Pendidikan Ekonomi. Vol 9, No 1.

[13] Rideout, E. C., Gray, D. O., 2013. Does entrepreneurship education really work? A review and methodological critique of the empirical literature on the effects of university - based entrepreneurship education. Journal of Small Business Management. Vol.51. No.3. Pp.329-351.

[14] Rumijati, A., 2010. Pengaruh Bakat Potensi Kewirausahaan Dan Metode Pembelajaran Terhadap Minat Berwirausaha Mahasiswa. Ekonomika-Bisnis, Vol. 01 No.0 :187-200.

[15] Shane, S., Locke, E. A., Collins, C. J., 2003). Entrepreneurial motivation. Human resource management review. Vol. 13. No. 2. Pp.257-279.

[16] Siagian, Sondang P., 2008. Manajemen Sumber Daya Manusia. Binapura Aksara. Jakarta, $1^{\text {st }}$ Edition.

[17] Suryana, 2013. Kewirausahaan: Kiat dan Proses Menuju Sukses. Salemba Empat. Jakarta.

[18] Wagner, J., 2007. Nascent Entrepreneurs In S. Parker (Red.) The Life Cycle of Entrepreneurial Ventures. Springer. US.

[19] Wennekers, A.R.M., Uhlaner, L.M., Thurik, A.R., 2002. Entrepreneurship and its Conditions: a Macro Perspective. International Journal of Entrepreneurship Education (IJEE). Vol.1. No. 1. Pp.25-64.

[20] Yuliatin, E., 2017. Pengaruh Lingkungan Kampus Dan Pendidikan Kewirausahaan Terhadap Minat Berwirausaha (Studi Kasus Pada Mahasiswa Program Studi Administrasi Bisnis Fakultas Ilmu Sosial Dan Ilmu Politik Universitas Mulawarman Samarinda Angkatan 2014-2016). eJournal Administrasi Bisnis, Volume 5, Nomor 4, 2017: 1091-1102. 